DOI: https://doi.org/10.24867/06AM02Racic

\title{
АНАЛИЗА СТРУЈАЊА У ЦЕНТРИФУГАЛНИМ ПУМПАМА ПРИМЕНОМ МЕТОДЕ КОНАЧНИХ ЗАПРЕМИНА
}

\section{FLOW ANALYSIS IN CENTRIFUGAL PUMPS USING THE FINITE VOLUME METHOD}

\section{Александар Рацић, Факултет техничких наука, Нови Сад}

\section{Област - МАШИНСТВО}

Кратак садржај - У раду је изведена $3 D$ нумеричка симулачија рада једне центрифугалне пумпе коришћеюем методе коначних запремина. Струјање у центрифугалним пумпама описано је помоћу Рејнолдсових осредњених Навије Стоксових једначина. У изиьу постизања нумеричке стабилности прорачуна извршена је оптимизачија нумеричке мреже. Симулација је изведена за случај нестачионарног струјања при различитим протоцима, а у ичиу анализирања струјања у радном колу и проточним деловима центрифугалне пумпе. Као резултат прорачуна добијена су поља брзина и притисака за различите радне режиме nумпе.

Кључне речи: Рачунарска динамика флуида, метод коначних запремина, иентрифугалне пумпе.

Abstract - Within the paper a $3 D$ numerical simulation of a centrifugal pump, using the finite volume method, was performed. The flow in centrifugal pumps is described using Reynolds averaged Navies-Stokes equations. In order to achieve numerical stability of calculation, optimization of numerical mesh was performed. The simulation was performed in case of unsteady flow for different flow rates, in order to analyze phenomena in the impeller and volute. such as pressure and velocity distribution.. As a result of calculation, fields of pressure and velocities for different operating points are obtained

Keywords: $C F D$, finite volume method, centrifugal pump.

\section{1. УВОД}

Предмет овог рада је анализа струјања у радном колу и проточним деловима центрифугалне пумпе применом методе коначних запремина, као једне од најпопуларнијих дискретизационих метода рачунарске динамике флуида (РДФ). РДФ представља један од алата при пројектовању и анализи свих типова турбомашина. Даје могућност обављања симулација и испитивања карактеристика пумпи без потребе за скупим експеримената, те уколико је коришћена на прави начин може да доведе до значајне уштеде времена.

Кориснички програми који се користе за нумеричке симулације базирају се на Навије-Стоксовим једначи-

\section{НАПОМЕНА:}

Овај рад проистекао је из мастер рада чији ментор је био др Слободан Ташин, доцент. нама и једначинама турбулентних модела којима је струјање флуида описано. Решавањем датих једначина добија се низ скаларних величина, чије се вредности додељују централним тачкама ћелија које чине нумеричку мрежу. У раду је изведена нумеричка симулација рада једностепене центрифугалне пумпе у корисничком програму STAR CCM+.

Симулације су урађене за случај нестационарног струјања течности кроз центрифугалну пумпу, у циљу одређивања радних карактеристика пумпе и анализирању поља притисака и брзина при константној брзини обртања пумпе.

Коришћена пумпа је названа ПУМПА 1. За ПУМПУ 1 је позната геометрија која одговара номиналној (оптималној) вредности протока $\mathrm{Q}=210 \mathrm{~m}^{3} / \mathrm{h}$ и напора $\mathrm{H}=50 \mathrm{~m}$ при брзини обртања радног кола пумпе од $1470 \mathrm{~min}^{-1}$.

\section{2. ПАРЦИЈАЛНЕ ДИФЕРЕНЦИЈАЛНЕ ЈЕДНАЧИНЕ И МАТЕМАТИЧКИ МОДЕЛ}

Почетни корак ка разумевању рачунарске динамике флуида представља сагледавање улоге парцијалних диференцијалних једначина у процесу нумеричких симулација. Проблеми у области механике флуида, описују се парцијалним диференцијалним једначинама. Спознаја ПДЈ представља неизоставан сегмент приликом решавања проблематике рачунарске динамике флуида у оквиру турбомашина.

\section{1 Турбулентно струјање}

Струјање унутар пумпе је у потпуности турбулентно па све струјне карактеристике као што су брзина, притисак и тангенцијани напон имају пулзирајући карактер који је приказан на слици 1.

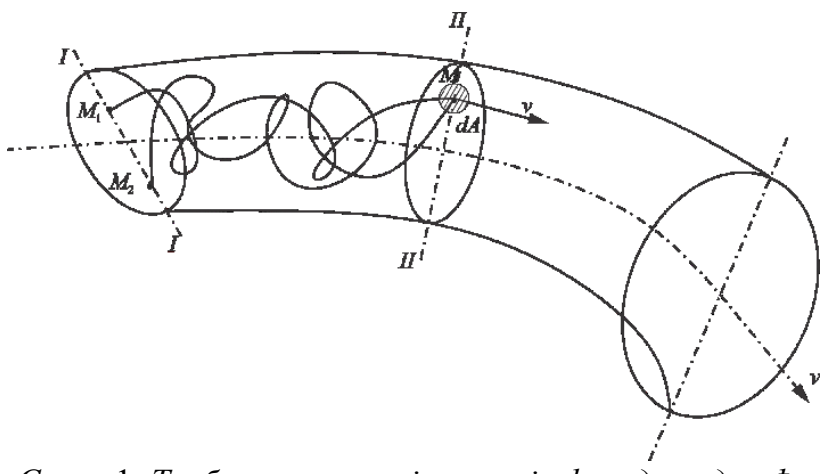

Слика 1. Турбулентне трајекторије флуидних делића и пулзачија брзине 
Услед таквог пулзирајућег карактера споменуте величине морају бити изражене преко просечних величина и величина тренутног одступања [2]:

$$
p=\bar{p}+p^{\prime} ; \tau=\bar{\tau}+\tau^{\prime} ; v=\bar{v}+v^{\prime},
$$

где су:

$p^{\prime}, v^{\prime}, \tau^{\prime}$ - тренутна одступања притиска, брзине и тангенцијалних напона,

$\bar{p}, \bar{v}, \bar{\tau}-$ просечне вредности притиска, брзине и тангенцијалних напона.

Једначине којима се описује турбулентно струјање унутар центрифугалне пумпе су Рејнолдсове осредњене Навије-Стоксове једначине и једначина континуитета, које записане у функцији од општих координата $\left(x_{i}\right)$ имају следећи облик [1]:

$$
\begin{aligned}
& \frac{\partial \bar{v}_{i}}{\partial t}+\frac{\partial}{\partial x_{j}}\left(\bar{v}_{i} \bar{v}_{j}\right)=-\frac{1}{\rho} \frac{\partial \bar{p}}{\partial x_{i}}+\frac{\partial}{\partial x_{j}}\left(v \frac{\partial \bar{v}_{i}}{\partial x_{j}}-\overline{v_{i}^{\prime} v_{j}^{\prime}}\right), \\
& \frac{\partial \bar{v}_{i}}{\partial x_{i}}+\frac{\partial \bar{v}_{j}}{\partial x_{j}}=0 .
\end{aligned}
$$

\section{2 Моделирање турбуленције}

Решавањем система једначина (2)-(3) добила би се струјна слика унутар пумпе. Међутим, број непознатих у овим једначинама је већи од броја једначина, па је неопходно дефинисати допунске услове, што се постиже различитим моделима турбуленције [2]. Моделирање турбуленције подразумева увођење одређених претпоставки о турбулентним напонима $\overline{v_{i}^{\prime} v_{j}^{\prime}}$ које резултирају допунским једначинама. У раду је коришћен $k$ - $\omega$ модел са 2 допунске једначине:

- једначина за турбулентну кинетичку енергију $k$

$$
\frac{\partial(\rho k)}{\partial t}+\frac{\partial\left(\rho \bar{v}_{j} k\right)}{\partial x_{j}}=\frac{\partial}{\partial x_{j}}\left[\left(\eta+\frac{\eta_{t}}{\sigma_{k}^{*}}\right) \frac{\partial \omega}{\partial x_{j}}\right]+P_{k}-\rho \beta^{*} \omega k
$$

и једначина за турбулентну фреквенцију $\omega$

$$
\frac{\partial(\rho \omega)}{\partial t}+\frac{\partial\left(\rho \bar{v}_{j} \omega\right)}{\partial x_{j}}=\frac{\partial}{\partial x_{j}}\left[\left(\eta+\frac{\eta_{t}}{\sigma_{\omega}^{*}}\right) \frac{\partial \omega}{\partial x_{j}}\right]+\alpha \frac{\omega}{k} P_{k}-\rho \beta^{*} \omega^{2} .
$$

Са једначинама (4) и (5) и одговарајућим граничним условима систем једначина (2)-(3) је решив (затворен), односно број непознатих је исти као и број доступних једначина.

\section{3. МЕТОД КОНАЧНИХ ЗАПРЕМИНА}

Метод коначних запремина је данас један од најкоришћенијих нумеричких метода. У већини проблема где је геометрија комплексна и где се мора формирати неструктуирана нумеричка мрежа овај метод је једино решење. Изузетно је лак за разумевање, јер сви чланови имају физички смисао.

Најједноставније речено, суштина методе коначних запремина састоји се у томе да се флуидни домен најпре издели на велики али коначан број, међусобно повезаних контролних запремина енгл. Control volume (CV). Интеграљењем задатог система ПДЈ по целој контролној запремини добија се вредност тзв. генералисане скаларне променљиве $\phi$, која се додељује централној тачки контролне запремине. Све наведене једначине могу се представити преко генерализоване транспортне једначине:

$\frac{\mathrm{d}}{\mathrm{d} t} \int_{V} \rho \phi \mathrm{d} V+\int_{A} \rho \phi \vec{v} \mathrm{ua}=J_{A} 1 \vee \varphi \mathrm{u}^{+}+J_{V} q_{\phi} \mathrm{d} V$

где чланови редом представљају:

- члан нестационарности,

- конвекциони члан,

- дифузиони члан,

- извор/понор.

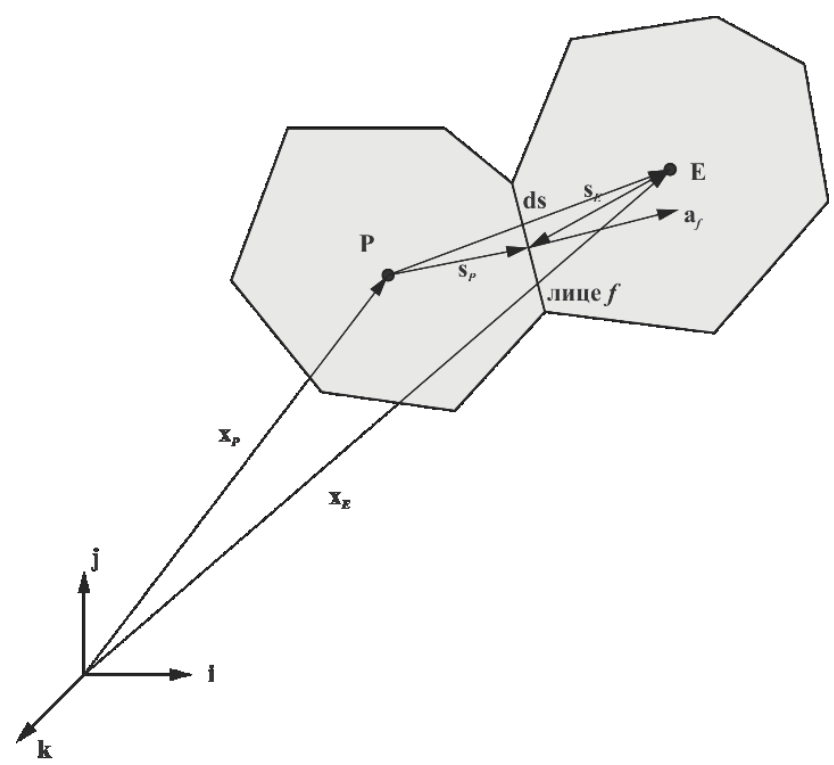

Слика 2. Две полиедарске контролне запремине

Интеграљењем једначина (6) по контролној запремини полиедарске ћелије (слика 2.) добија се вредност генералисане скаларне променљиве $\phi_{P}$, у централној тачки, која зависи од вредности генералисаних скаларних промењивих из суседних мрежних тачака $\phi_{n}$. На овај начин формира се низ алгебарских једначина следећег облика:

$$
\frac{a_{P}}{\omega} \Delta \phi_{P}+\sum_{n} a_{n} \Delta \phi_{n}=r_{o}
$$

где су:

$a_{P}-$ коефицијент генералисане скаларне величине у централној тачки $P$,

$a_{n}$ - коефицијент генералисане скаларне величине у било којој централној тачки,

$r_{o}$ - нумерички остатак.

Сукцесивним решавањем система алгебарских једначина (7) долази се до вредности генералисаних скаларних величина у свим централним тачкама а самим тим и до карактеристика струјног поља.

\section{4. ГЕОМЕТРИЈА И НУМЕРИЧКИ ДОМЕН}

Можда и најбитнији корак у нумеричким симулацијама представља правилно дефинисање геометрије проблема и креирање нумеричког домена тј. нумеричке мреже [3]. 


\section{1 Геометрија пумпе}

У Табели 1. приказане су димензије радног кола и спирале.

Табела 1. Димензије пумпе

\begin{tabular}{|l|c|c|}
\hline Параметар & Вредност & Опис \\
\hline \multicolumn{3}{|c|}{ Радно коло } \\
\hline$d_{0}$ & $145 \mathrm{~mm}$ & пречник усисног грла радног кола \\
\hline$d_{1}$ & $142 \mathrm{~mm}$ & пречник радног кола на улазу \\
\hline$b_{I}$ & $36,3 \mathrm{~mm}$ & ширина радног кола на улазу \\
\hline$\beta_{I L}$ & $24^{\circ}$ & лопатични угао на улазу у радно коло \\
\hline$d_{2}$ & $394 \mathrm{~mm}$ & пречник радног кола на излаз \\
\hline$b_{2}$ & $17 \mathrm{~mm}$ & ширина радног кола на излазу \\
\hline$\beta_{2}$ & $28,3^{\circ}$ & лопатични угао на излазу из радног кола \\
\hline$z$ & 6 & број лопатица \\
\hline$\delta$ & $4 \mathrm{~mm}$ & дебљина лопатица \\
\hline$n_{s q}$ & 18,88 & специфична брзина обртања пумпе \\
\hline \multicolumn{3}{|c|}{ Спирала } \\
\hline$R_{3}$ & $205 \mathrm{~mm}$ & полупречник базе спирале \\
\hline$b_{3}$ & $34 \mathrm{~mm}$ & ширина спирале \\
\hline$d_{I I}$ & $100 \mathrm{~mm}$ & спољашњи пречник дифузора \\
\hline
\end{tabular}

\section{2 Нумерички домен}

На основу података из табеле 1. пројектована је геометрија пумпе, из које је користећи болеан (Boolean) операције, креиран флуидни домен. Да би се од флуидног домена добио нумерички, потребно је флуидни домен изделити на велики али коначан број контролних запремина (ћелија), по којима се интеграле парцијалне диференцијалне једначине. На слици 3. се може видети нумерички домен (мрежа) пумпе. На улазу у радно коло и на излазу из дифузора спирале налазе се продужеци домена.

Дати продужеци изводе се ради спречавања рециркулације течности на улазу и излазу. Препорука је да износе 5-7 дужина пречника на улазу/излазу.

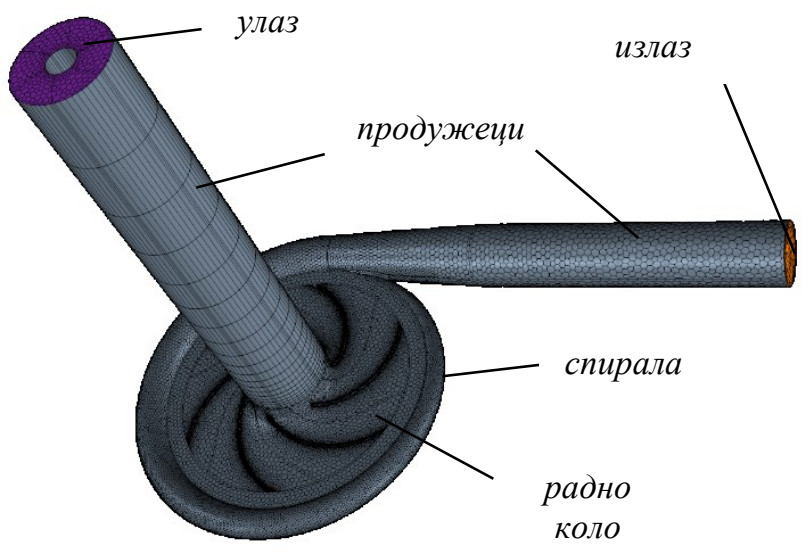

Слика 3. Нумеричка мрежа

Нумеричка мрежа оформљена за потребе симулације је неструктуирана и састављена од полиедарских ћелија. Поступак формирања мреже у случају центрифугалних пумпи, није једноставан. Потребна су подешавања мреже на местима где постоји интензиван транспорт флуидних величина.

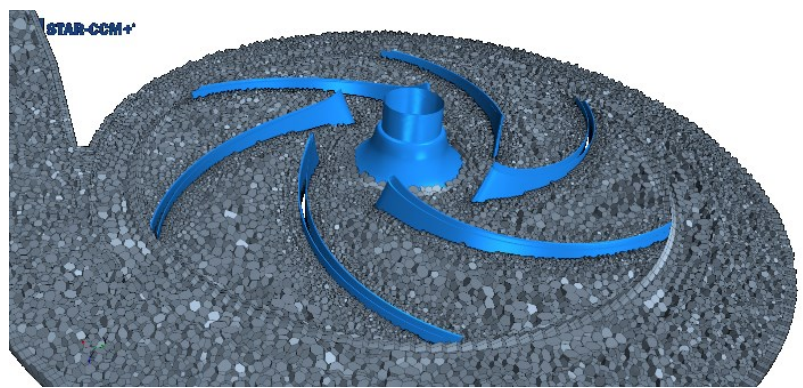

Слика 4. Мрежа у радијалном пресеку радног кола

Са слике 4. се може видети да је густина мреже већа око лопатица радног кола, као и на излазу. То се постигло постављањем додатних призматичних слојева на тим местима. Посебна пажња је посвећена површини на којој долази до клизања ротора и статора, као и површинама које ограничавају флуидни домен, како би утицај зидова спирале био узет у обзир. Осцилације у нумеричким решењима могу упућивати на лошу обраду мреже у овим деловима. Адекватним пројектовањем геометрије и формирањем квалитетне нумеричке мреже остварује се директан утицај на тачност резултата симулације.

У табели 2. се може видети бројно стање ћелија по регијама. Очигледно, највећи број ћелија је у радном колу услед најучесталијег транспорта флуидних величина.

Табела 2. Број ћелија по регијама пумпе

\begin{tabular}{|lc|}
\hline Регија & Број ћелија \\
\hline продужетак на улазу & 8720 \\
\hline продужетак на излазу & 6936 \\
\hline спирала & 59937 \\
\hline радно коло & 355150 \\
\hline УКУПНО & 430743 \\
\hline
\end{tabular}

\section{5. РЕЗУЛТАТИ}

Симулације су изведене за пет различитих протока $1,4 Q, 1,2 Q, Q, 0,8 Q, 0,5 Q$, где је $Q=210 \mathrm{~m}^{3} / \mathrm{h}$, при константној брзини обртања радног кола од $1470 \mathrm{~min}^{-}$ 1

Табела 3. Гранични услови

\begin{tabular}{|c|c|c|}
\hline Граница & $\begin{array}{c}\text { Гранични } \\
\text { услов }\end{array}$ & Опис \\
\hline Улаз & $\begin{array}{l}\text { Stagnation } \\
\text { inlet }\end{array}$ & $p_{t}=p_{d}=\frac{1}{2} \rho v^{2}$ \\
\hline Излаз & $\begin{array}{c}\text { Pressure } \\
\text { outlet }\end{array}$ & $i^{\cdot}[\mathrm{kg} / \mathrm{s}]$ (Mass Flow Rate) \\
\hline $\begin{array}{l}\text { Зидови спирале } \\
\text { и зидови радног } \\
\text { кола }\end{array}$ & Wall & Не клизајућа површина (No Slip). \\
\hline $\begin{array}{l}\text { Зидови на } \\
\text { продужецима на } \\
\text { улазу и излазу }\end{array}$ & Wall & Клизајућа површина (Slip). \\
\hline RSI & Interface & $\begin{array}{l}\text { Mixing plane (стационарно } \\
\text { струјање), } \\
\text { In place (нестационарно } \\
\text { струјање). }\end{array}$ \\
\hline
\end{tabular}




\section{1 Нестационарно струјање}

Симулације нестационарног струјања захтевају дефинисање временског корака. За његово дефинисање не постоји тачна формула али постоје препоруке којих се треба држати. Препорука је да временски корак буде време за које би се лопатица померила $0,5^{\circ}$ до $1^{\circ}$ степена у кружном правцу. Усвојен временски корак je $\Delta t=10^{-4}$.

При нестационарном струјању као решења добијена су поља притиска и поља брзина која су приказана на сликама 5, 6 и 7. Такође, исцртани су дијаграми радних карактеристика пумпе $H=f(Q)$, и $\eta=f(Q)$.

\subsection{1 Скаларна поља притиска и векторска поља брзина}

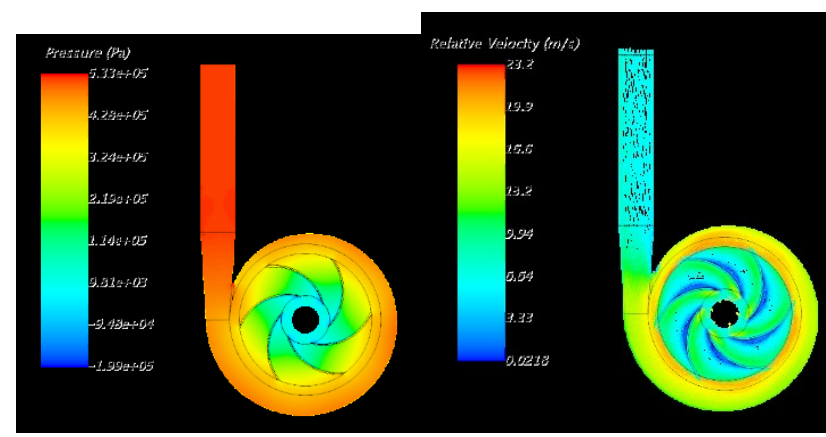

Слика 5. Скаларно поље притисака и векторско поље брзина при $Q$

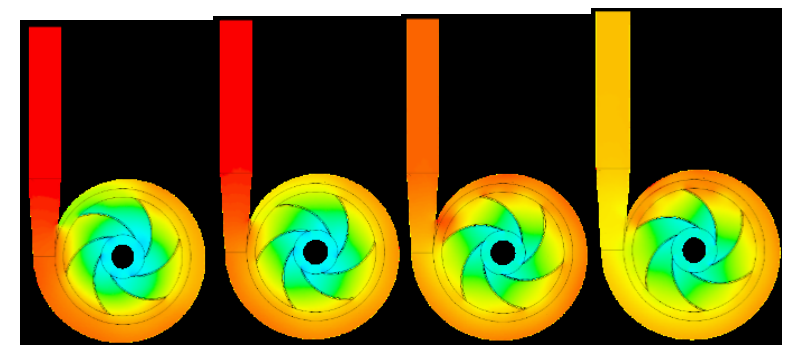

Слика 6. Скаларно Поље притисака при $0,5 Q_{o p t}, 0,8 Q$, $1,2 Q$ и $1,4 Q$

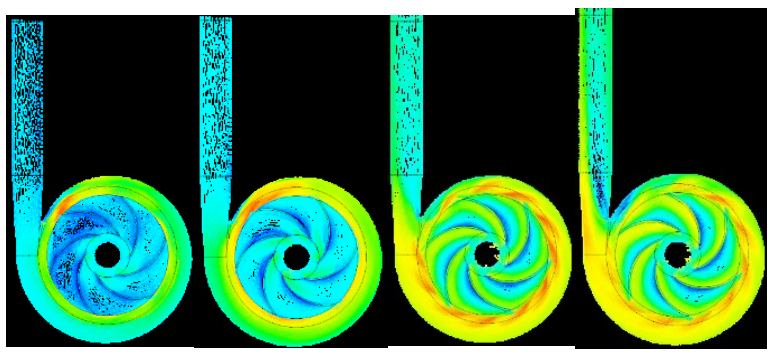

Слика 7. Распоред вектора брзина при 0,5Q, 0,8Q, $1,2 Q$ и $1,4 Q$

Са слике 5. се види да је распоред притисака у радном колу и спирали униформан са повољним градијентима. При протоцима нижим и вишим од оптималних (слика 6.) распоред притисака постаје све неуниформнији што доводи до појаве радијалних сила у радном колу, које негативно утичу на животни век пумпе. При изузетно ниским протоцима при проласку лопатице поред језичка долази до наглог пада притиска, где може доћи до појаве кавитације. Векторско поље брзина при оптималном протоку указује на очекиван распоред брзина. На леђној страни лопатица долази до гомилања струјница те је ту локално већа брзина, док је на грудној мања, самим тим је условљен и распоред притисака на леђној односно грудној страни лопатице. Унутар радног кола у лопатичном каналу примећује се појава вртлога и одлепљивања флуидне струје што указује на могућ лош одабир облика и димензија лопатица. При изузетно ниским протоцима примећена је појава вртложења на самом улазу течности у радно коло, док је при високим протоцима примећено одлепљивање флуидне струје при уласку у дифузор спирале (слика 7.).

\subsection{2 Радне карактеристике пумпе}

Дијаграм 1. Радне карактеристике пумпе при $n=1470$ $\min ^{-1}$

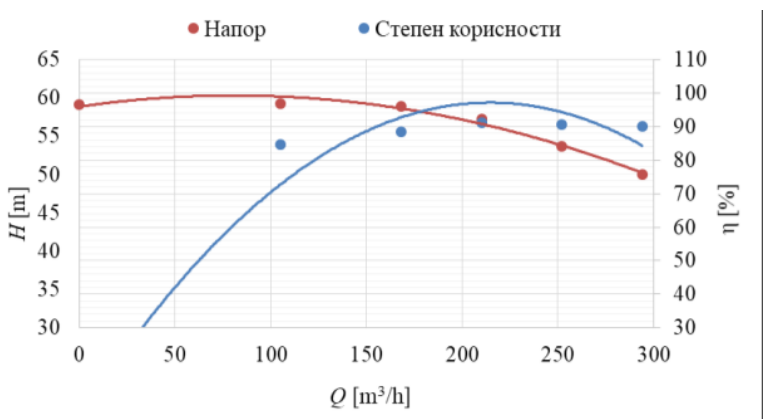

Са дијаграма 1. се потврђује да је највећа ефикасност управо при оптималном протоку $Q=210 \mathrm{~m}^{3} / \mathrm{h}$.

\section{6. ЗАКЉУЧАК}

Изведена је анализа струјања кроз центрифугалну пумпу користећи STAR CCM+ кориснички програм. На распоред притисака и векторског поља брзина директан утицај има величина протока. Закључено је да се при оптималним условима постиже највиши степен корисности пумпе. Забележени су феномени унутар лопатичног канала као што су појаве вртлога услед одлепљивања струје флуида и појаве вртлога на улазу у радно коло.

\section{7. ЛИТЕРАТУРА}

[1] Букуров Ж., „Механика Флуида“, Факултет техничких наука, Нови Сад, (1967), 321-360.

[2] „The Third Summer School of CFD“, Faculty of Technical Sciences, University of Novi Sad, Serbia, (2019), 20-24.

[3] Best Practices for Modeling Centrifugal Pumps, https://thesteveportal.plm.automation.siemens.com, (2018).

\section{Кратка биографија:}

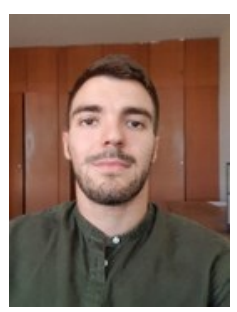

Александар Рацић рођен је у Новом Сад 1994. год. Дипломирао је 2017 год., ні Факултету техничких наука у Новом Саду студијски програм Енергетика и процесн: техника, а мастер рад на истом програму и: области Механика флуида одбранио је 2019 године.

Контакт: aleksandar.racic.ns@gmail.com 